\title{
MEASURING THE EFFECT OF SOCIAL NETWORKING, ORGANIZATIONAL CULTURE TOWARD EMPLOYEE ENGAGEMENT IN SOES ORGANIZATION: CASE STUDY OF SOES IN INDONESIA
}

\author{
Victor Wiley
}

Thomas Lucas

\author{
Riset Inovasi Bisnis, Jakarta Selatan \\ Email: victorwiley10@gmail.com, thomasreliable10@gmail.com
}

\begin{abstract}
SOEs in Indonesia has been expanded their project with tight time and more challenged business climate. In fact, similar to private organization, SOEs also faced with employee performance in their projects. The employee performance has many aspects of social networking, organizational culture and employee engagement. This study tested the influence of social networking, organizational culture and employee engagement on in several projects which ventured by State Owned Enterprises in Indonesia. The variables are analyzed by using SEM AMOS. It is explained that social networking, organizational culture and employee engagement affect employee engagement in SOEs-based projects in Indonesia. This study suggested an approach to improve social networking, organizational culture and employee engagement as new strategies for SOEs in Indonesia. This study result can be a recommendation to the SOEs managers to maintain social networking, organizational culture and employee engagement in order their project to be manageable.
\end{abstract}

Keywords: employee engagement; organizational culture; and social networking. 


\section{INTRODUCTION}

There is now an emphasis on maximizing employee engagement within the organization and promoting a more inclusive culture where employees are encouraged to present their views (Macey, et al., 2011; Barabâsi, et al., 2002). The Internal Social Network facilitates more organized organizational communication (Valenzuela, et al., 2009; Cornelissen, J., \& Cornelissen, 2017).

The Internal Social Network is used to align goals cross department and divisions (Mergel, I.2016 ;Cornelissen, J., \& Cornelissen, 2017). Multinational companies tend to launch products / strategies globally but before products / strategies are available to the public, it's important for your employees to get to know them so they can become adequate brand ambassadors. The internal launch empowers employees to help drive the external launch by sharing corporate news and speaking on behalf of brands (Snyder, T., \& Honig, D. 2016;). When Senior Management is active in the Social Media platform, other employees tend to follow, therefore it is important that important news is communicated by top management (Men, L \& Tsai, 2015).

Groups and discussion boards can be easily created on social media platforms that let certain departmental and division employees share them that are relevant to them (Huang, et al., 2015; Men, L \& Tsai, 2015). Transparency on social networking platforms allows management to process projects and initiatives that employees have made and provide them with guidance where necessary (Cornelissen \& Cornelissen, 2017; Vanclay, et al., 2015). Employees can show 
support for their peers by voting for those who in turn improve employee morale and inspire them to perform better.

Employees as human have various personality traits and also both rational, emotional and motivational influenced by a number of factors, such as a sense of satisfaction for the achievement of job targets and social networking (Izard, 2013; Amdurer,et al., 2014). In addition, they also faced with the issues of social networking, organizational culture and employee engagement (Derks, et al., 2015).

As they get high burden duty and tight time deadline tasks, they consider their job as challenging and full stressing situation. Such condition has been great issues and topic in many literature mainstreams. However, there is no novelty discussing the task challenge and social Stress anticipation from employee's perspective. In addition, for high performance project implemented by SOEs, there is a gap that is not resolved till today in human resources literature review. Therefore, this study proposes the aspects of social networking, organizational culture and employee engagement and how the variables can impact on the employee motivation on state-owned companies in Indonesia. The results of this study are expected to provide input to SOEs managers in Indonesia.

Social Networking. Some studies have discussed the relationship of social networking skill and their role to employee engagement (Macey, et al., 2011; Barabâsi, et al., 2002). Albrecht, et al., (2015) reported that organizations which focused on successful talent management goals, organizations must move beyond employee motivation strategies and high employee engagement. Having engaged employees has become important as organizations get wide scale projects which 
needs expanded initiative, innovation, and proactive responsiveness to project goals (Child, 2015). The employee engagement has been this important element affecting organizational effectiveness, innovation, and competitiveness (Welch, 2011). As mentioned by Short, K. (2016) That manager-employee relation is influenced by the relationships of employees and organizations which shaped to work retention and pride sentiment to their workplace. As employee has higher social networking, they also will have more frequent engagement either toward their team or their managers and stakeholders. Based on the assumption, we propose first hypothesis. H1 : There is a positive and significant influence between social networking on employee engagement.

Organizational Culture. While the concept of organizational culture gained great attention from researchers, attention was limited to investigating performance results at the organizational level but not on the project scale. Jiao, and Zhao, (2014) Argued that investigation of employee performance must be based on their readiness to accept task burden and bring their team into more innovative team behavior. However, there is few empirical investigations discussed the phenomena such as the relationship between organizational culture and employee output levels (Pinder, 2014; Slack, et al., 2015; Albrecht,et al., 2015). Thus, although organizational culture is believed to affect the construction of organizations, groups and individuals, such research only tries to identify employee behaviors and attitudes influenced by organizational culture and is still limited. Similarly, the research involvement literature has called for a broader contextual investigation of other factors that impact employment engagement (Bakker et al., 2014; Alagaraja, 
M., \& Shuck, B. 2015; Huhtala, et al., 2015). Furthermore, or wide scale organization such as SOES, they are faced with extreme work burden and tight time deadline which impacted on the teamwork become more challenging. In addition, when the team also consisted of diverse people with difference culture, they have to adjust them self into cross culture sense making and value openness among their team members. Based on the explanation, we propose second hypothesis.

$\mathrm{H} 2$ : There is a positive and significant influence of organizational culture on employee engagement in the SOE company in Indonesia.

Stress Anticipation. Employee involvement has become an important social milieu that enables interpersonal communication among team members to share and create information about their work and duty (Katzenbach and Smith, 2015; Eisenberger, et al., 2015). Employee involvement also has been studied from psychological perspectives especially the personality traits to handle task challenge and social stress in team interaction (Tims, et al., 2015; Wang, et al., 2015). People with high task challenge ability will be able to handle their task and finally can anticipate social stress burden.

Team members who were more likely to engage in team-based relationship will spend more time and more likely to be multitaskers (Bell \& Outland, 2017; Pluut, et al., 2014). They can handle task challenge and better interaction mode. Additionally, those who has higher frequency of interaction also has higher information about their team situation (Bell \& Outland, 2017; Pluut, et al., 2014). They establish interaction through mobile communication or face-to-face mode. Meanwhile, team members or employees with higher frequency of interaction also 
has high satisfaction toward their team performance and finally lower stress burden (Leiter, et al., 2015; García-Buades et al., 2016). However, it is argued that employees with more work duration also faced with higher psychological stress (e.g., psychological tension, work strain, job burden) that is difficult to manage or endure (Gross, 2017) . In addition, traumatic stress from certain long term project can lead to detrimental stress which lead to threatening stimuli . It is supported by Gold, P. W. (2015) that acute stress response can lead to workplace stress. The stress is considered a major contributor to troubled teamwork and finally ubiquity of potential sources of teamwork crash especially in big project.

Employee who experience stress all or nearly all of their working time will have lower task challenge ability and higher social stress due to lack of knowledge and preparation toward their job duty (Sonnentag \& Fritz, 2015; Wang, et al., 2015). However, there is low attention about the employee engagement in team-based project and the team member interaction to handle the task and stress during project implemented (Eisenberger, et al., 2016; Jeve, et al., 2015). In this context, a better understanding of the team member's personality and their ability in task fulfillment are important in order they can handle their burden at workplace (Whiting ., \& Maynes, 2016). However, it is debated that employee with certain personality trait will handle the task and social stress better. Their lack of evidence that perceived stress in the United States population has increased especially in big project (Schabram, \& Maitlis, 2017).

Since people have various stress resilience, team member with higher ability of task challenge also need strategy to handle their job stress and this strategy is 
becoming increasingly relevant for the team to increase their performance. The team experience in caring their members to handle the job burden is valuable strategy to finish their project with higher team performance.

H3 : There is a positive and significant influence of Social Stress Anticipation on employee engagement in the SOE company in Indonesia.

\section{METHODOLOGY}

Research design determine the processes of research from planning and execution of the research (Marshall and Rossman,2014). In a narrower sense, the research design is only about data collection and analysis alone (Palinkas, et al., 2015). The research design is a structured work plan to explain the relationships among variables and the respondents/ participants involved in the study. It is aimed to find results as answers to research questions.

As this study observed SOEs employees and how their personality traits and social stress anticipation are implemented, this study will ask the respondents and their experience about task challenge and their stressful work burden situation. The respondents' demographics are given in Table 1.

Table 1.

Respondents demographics in this study

\begin{tabular}{lll}
\hline \multirow{2}{*}{ Respondents } & Total \\
\cline { 2 - 3 } & People & $\mathbf{\%}$ \\
\hline Respondents gender & & \\
\hline$\bullet \quad$ Men & 111 & $55,5 \%$ \\
$\bullet \quad$ Women & 89 & $44,5 \%$ \\
\hline Respondents by business type & & \\
\hline$\bullet \quad$ Bank & 97 & $48,5 \%$ \\
- Insurance & 29 & $14,5 \%$ \\
$\bullet \quad$ Telecommunication & 26 & $13 \%$ \\
& 21 & $10,5 \%$
\end{tabular}




\begin{tabular}{cll}
$\bullet \quad$ PTPN & 13 & $6,5 \%$ \\
$\bullet \quad$ Mining & 14 & $7 \%$ \\
\hline Respondents age & & \\
\hline$\bullet \quad 25-30$ years & 15 & $7,5 \%$ \\
$\bullet \quad 30-35$ years & 49 & $24,5 \%$ \\
$\bullet \quad 35-40$ years & 87 & $43,5 \%$ \\
$\bullet \quad 40-45$ years & 25 & $12,5 \%$ \\
$\bullet \quad 45-50$ years & 16 & $8 \%$ \\
$\bullet \quad$ 50 years & 8 & $4 \%$ \\
\hline Respondents' education level & & \\
\hline & SD/SMP (primary, secondary) & \\
$\bullet \quad$ SMA & 9 & $4,5 \%$ \\
$\bullet \quad$ High (D3, S1,) & 154 & $77 \%$ \\
- S2 and S3 & 37 & $18,5 \%$ \\
\hline
\end{tabular}

Source: interview results which processed by author

Based on Table 1, it is known that the majority of respondents gender are 111 men $(55.5 \%)$ and 89 women (44.5\%). Most of them work as state-owned Bank employees 97 people (48.5\%), Insurance 29 people (14.5\%), Contractors 26 people (13\%), telecommunications 21 people $(10.5 \%)$, PTPN 13 people $(6.5 \%)$. For this group and as generally studied, that employee engagement in banking industry has been demanded on diversity of thinking, high work motivation and rapid social learning styles.

Meanwhile, based on age, our study collected about 87 respondents (43.5\%) aged 35-40 years, 49 people (24.5\%) age 30-35 years, 25 people (12.5\%) aged 4045 years, and 16 people (8\%) aged $45-50$ years age. While the respondents education level are high education (D3 and S1) about 154 people (77\%), graduate master education 37 people $(18.5 \%)$ and high school education 9 people $(4.5 \%)$. For this group, it indicated by high task burden and cross culture diverse which impacted on their engagement in team and organizational activities. 


\section{RESULTS AND DISCUSSION}

As we tested the social networking, we also measure the employee personality traits and their adaptation toward task challenge and stress anticipation. This study used reliability test to estimate the extent to which a measuring instrument can give relatively the same results when re-measured on the variables. The reliability test in SEM used generalized formula as below (Kline, 2015).

Table 2.

Test Results Reliability and Validity

\begin{tabular}{|c|c|c|c|}
\hline Research constructs and research items & $\begin{array}{l}\text { Loadi } \\
\text { ng } \\
\text { factor } \\
\text { s } \\
>0.5\end{array}$ & $\begin{array}{l}\text { Composi } \\
\text { te } \\
\text { reliabilit } \\
y>0.7\end{array}$ & $\begin{array}{l}\text { Ave. var. } \\
\text { extracted } \\
>0.5\end{array}$ \\
\hline
\end{tabular}

Social networking

Feedback, Praise and Awards

- Giving feedback to the subordinates at the right time .845 and effective

- Providing specific, positive, and constructive feedback $\quad .871$

- Gain respect for the achievement of crew / team .742 members effectively

Team task challenges

- task burden adjustment. Provision of guidance so that $\quad .767$ the subordinates can achieve the targets given

- Value openness. providing suggestions so that the .798 subordinates can improve the quality of work

- innovative behavior. Boss identifies obstacles and .684 provides guidance to the subordinates to solve work problems

- $\quad$ cross culture sense making. Team can meet regularly to discuss obstacles and complete each other to handle culture diversity

Authority and Empowerment

$0.81 \quad 0.59$

- The boss opens opportunities for the subordinates to $\quad .754$ give ideas and feedback

- Giving an opportunity to the subordinates to provide $\quad .807$ an alternative way of problem solving

- Providing support for the decision of the subordinate $\quad .747$ in the case of problem solving

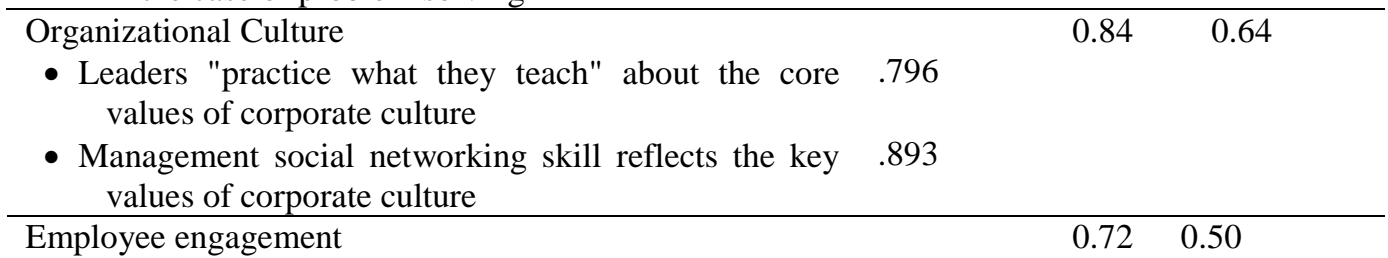


- I have the opportunity to do work according to ability $\quad .804$

- I feel able to take advantage of the skills I have $\quad-.132$

- wages given according to my work $\quad .848$

- the wages I receive are still less than those of other .786 companies

- Employees have high involvement in their work $\quad .713$

$\begin{array}{lll}\text { Stress anticipation } & 0.76 & 0.55\end{array}$

- Employees are actively prevent work stress to improve $\quad .532$ themselves, co-workers and companies

- Opportunities to contribute to employee-related .857 decisions

- Feeling enthusiastic and enthusiastic about going to .806 work every day

Source: Author, Statistical Analysis Results (2018)

Discriminate validity test by using AVE value is done by comparing the root value of AVE of each construct with correlation between construct with other construct. As this study measured the construct of social networking, it also determining that personality traits, task challenge and social stress anticipation as the sub indicators. From Gallardo et al., (2014) it is recommended that AVE values both the three sub indicators should be greater than 0.50 . Based on Table 2 , it showed that the root value of each construct AVE is greater with the correlation between constructs with other constructs. Therefore, it brings us to get insight that the three sub indicators can be a good discriminant validity metrics. Based on the results of the calculated metrics, then all constructs in this study feasible to use. It is also similar to organizational culture, and employee engagement.

For organizational culture which consisted team challenge mindset, task burden adjustment, value openness, innovative behavior and cross culture sense making, they are tested from AVE values toward. Employee engagement. Analysis of data processing result at full stage of SEM model is done by doing conformity test and statistic test toward the sub indicators of diversity of thinking, social 
learning styles and work motivation. The test results containing goodness-of-fit model are given in Table 3.

Table 3.

Test Results Goodness-of-fit model

\begin{tabular}{lllll}
\hline No & Index & Critical Value & Results & $\begin{array}{l}\text { Model } \\
\text { Evaluation }\end{array}$ \\
\hline 1 & Chi-Square & Approaching zero & 336.726 & Not fit \\
2 & Probability level & $\geq 0,05$ & 0,001 & Not fit \\
3 & CMIN/DF & $\leq 5.00$ & 2.053 & Fit \\
4 & CFI & $\geq 0,90$ & .947 & Fit \\
5 & RMSEA & $\leq 0,08$ & .079 & Fit \\
6 & TLI & $\geq 0,90$ & .920 & Fit \\
7 & GFI & $\geq 0,90$ & .882 & Marginal \\
8 & AGFI & $\geq 0,90$ & .806 & Marginal \\
\hline
\end{tabular}

Source: Data Processed From Research Results 2018

Based on the test results, the GFI score shows marginal results. Although GFI is considered marginal but still able to fulfill the requirement, because the test is not good or marginal result is two test, whereas in this model only one has marginal value, so that the proposed model is assessed Good enough and acceptable as the appropriate model in this study.

Table 4.

SEM Test Results

\begin{tabular}{llll}
\hline Variables/relations & & $\begin{array}{l}\text { Standardized } \\
\text { coefficients }\end{array}$ & C.R. \\
\hline Social Networking & Personality traits & 0.501 & 4.469 \\
\hline & Task challenge & 0.507 & 3.308 \\
\hline Organizational Culture & Social Stress Anticipation & 0.648 & 3.406 \\
\hline & Team Challenge mindset & 1.000 & \\
\hline & Task burden adjustment & 1.061 & 3.140 \\
\hline & Value openness & 0.96 & 12.773 \\
\hline Employee Engagement & Innovative behavior & 0.531 & 12.087 \\
\hline & Cross culture sense making & & 10.906 \\
\hline & Diversity of thinking & 0.975 & 11.867 \\
\hline
\end{tabular}




\begin{tabular}{|c|c|c|c|}
\hline & Supportive working condition & 1.000 & \\
\hline \multicolumn{4}{|c|}{ Supportive colleagues } \\
\hline \multirow[t]{3}{*}{ Stress anticipation } & Rational & 0.956 & 8.524 \\
\hline & Emotional & 0.631 & 6.731 \\
\hline & Motivational & & \\
\hline \multicolumn{4}{|l|}{ Paths: } \\
\hline \multicolumn{2}{|c|}{ Social networking - Employee Engagement } & 0.601 & 3.121 \\
\hline \multicolumn{2}{|c|}{ Corporate Culture - Employee Engagement } & 0.468 & 8.524 \\
\hline \multicolumn{2}{|c|}{ Stress anticipation - Employee Engagement } & 0.569 & 3.741 \\
\hline
\end{tabular}

Source: Data Processed From Research Results 2018

\section{RESULT AND DISCUSSION}

Based on the results of the study note that there is a significant influence between social networks with the involvement of employees with high scores $(\beta=$ 0.601) then Ho is rejected and $\mathrm{Ha}$ is accepted, meaning that there is a positive influence between social networks and employee involvement. (Macey, et al., 2011; Barabasi, et al., 2002). Albrecht, et al., (2015) reported that for organizations that focus on successful talent management goals, organizations must move beyond employee motivation strategies and high employee involvement. Short, K. (2016) That manager-employee relationship is influenced by employee and organizational relationships that are formed for work retention and feeling proud of their workplaces. Because employees have a higher social network, they will also be more often involved either with their team or their managers and stakeholders. This is evidence in our study that in the $\mathrm{H} 1$ hypothesis, there is an influence of social networking on employee involvement which means the hypothesis is accepted. It makes sense because social networking can inspire employees who give employees freedom in making decisions. Thus managers can increase the commitment and dedication of their employees by fostering encouragement, inspiration, focusing on 
efforts and finally communicating expectations to employees (Mone and London, 2014).

The testing result above found that there is significant influence between organizational culture with employee engagement there is value $(\beta=0,468)$ hence Ho refused and $\mathrm{Ha}$ accepted. The positive influence between organizational cultures with employee engagement brings us to accept the $\mathrm{H} 2$ hypothesis since there is influence of organizational culture on employee engagement. As organizational culture is shaped by team challenge mindset and task burden adjustment, it also demanded value openness to cross culture situation to bring the team to nurture innovative team behavior (Luthans, et al., 2015). The analysis testing also showed that sub-variables organizational culture and their five subcategories (e.g., team challenge mindset, task burden adjustment, value openness, innovative behavior, and cross culture sense making) have significant influence on sub-variable employee engagement with high validity and consistency (Olla,2013). Team challenge mindset represents the positive effect on dedication and absorption (Olla,2013). While sub variable consistency has a significant positive influence on employee engagement. This means that the clearer the vision, mission of the company will bring the team to more closer target, to achieve the target and finally higher employee involvement in work. In addition, the task burden adjustment toward value openness and cross culture sense making also related to enthusiastic, inspired, and proud of his work. It means that clarity of vision, corporate mission, and targeting strategy will bring the employees, the team and company to have full concentration in work. 
The test results above found that there was a significant effect between Social Stress Anticipation with employee involvement there was a value $(\beta=0$, 569) then Ho was rejected and Ha was accepted. The positive influence between Social Stress Anticipation and employee involvement leads us to accept the H3 hypothesis because there is an influence of Social Stress Anticipation on employee involvement. Employee involvement has also been studied from a psychological perspective especially personality traits to deal with task challenges and social pressures in team interactions (Tims, et al., 2015; Wang, et al., 2015). People with high task challenge abilities will be able to handle their tasks and can finally anticipate the burden of social stress. In this context, a better understanding of the personality of team members and their ability to fulfill tasks is important so that they can handle their burden at work (Whiting, \& Maynes, 2016). However, it is argued that employees with certain personality traits will handle tasks and social pressures better. Lack of evidence that perceived stress in the United States population has increased especially in large projects (Schabram, \& Maitlis, 2017).

\section{CONCLUSION}

Increased employee engagement can increase the productivity and profitability of the company, while also lowering the absenteeism and turnover of employees. Entrepreneurs who feel the commitment and engagement of the engaged employee will always direct their primary attention to the achievement of the set goals and goals, but they also do not unmind in looking for opportunities to contribute further in achieving the mission and goals of the company. Engaged 
employees in their teamwork represent their intention to support the project and finally successful teamwork since it gives a full sense of accomplishment as a professional employee.

It is concluded that employees' daily behavior must be directed to effective social networking and help them to find strategy to handle the work challenge in order they can adjust to task burden and finally establish innovative behavior. Each employee must be given opportunities in practicing their social networking. It is getting important when they faced with tight time of projects and finally they must sustain their working team work with diverse member cultures. As they also have to be independent, they also have to maintain their social networking when team members need supervision to handle their task challenge.

Based on the above observations, this study finally concluded that organizational culture can be adapted to bring team to be more effective after they can modify the team preparation to value appends and innovative behavior.

From the employee perspectives, they can practice the diversity of thinking, they also have to improve the employee social learning styles and drive the employee to nurture their work motivation. The manager can ask for their team members about type of work motivation and also the aspects of effective social networking either as experience, skills, competence or best practices. Employees with wider opportunity will have improved experience about social networking as reflected in innovative behavior in managing interpersonal relationships which finally establish and fulfill organizational goal. 


\section{REFERENCES}

Alagaraja, M., \& Shuck, B. (2015). Exploring organizational alignment-employee engagement linkages and impact on individual performanc

Albrecht, S. L., Bakker, A. B., Gruman, J. A., Macey, W. H., \& Saks, A. M. (2015). Employee engagement, human resource management practices and competitive advantage: An integrated approach. Journal of Organizational Effectiveness: People and Performance, 2 (1), 7-35.

Amdurer, E., Boyatzis, R. E., Saatcioglu, A., Smith, M. L., \& Taylor, S. N. (2014). Long term impact of emotional, social and cognitive intelligence competencies and GMAT on career and life satisfaction and career success. Frontiers in psychology, 5.

Barabâsi, A. L., Jeong, H., Néda, Z., Ravasz, E., Schubert, A., \& Vicsek, T. (2002). Evolution of the social network of scientific collaborations. Physica A: Statistical mechanics and its applications, 311 (3-4), 590-614.

Bell, S. T., \& Outland, N. (2017). Team Composition Over Time. In Team Dynamics Over Time (pp. 3-27). Emerald Publishing Limited.

Child, J. (2015). Organization: contemporary principles and practice. John Wiley \& Sons.

Cornelissen, J., \& Cornelissen, J. P. (2017). Corporate communication: A guide to theory and practice. Sage.

Derks, D., Duin, D., Tims, M., \& Bakker, A. B. (2015). Smartphone use and workhome interference: The moderating role of social norms and employee work engagement. Journal of Occupational and Organizational Psychology, 88 (1), 155-177.

Eisenberger, R., Malone, G. P., \& Presson, W. D. (2016). Optimizing perceived organizational support to enhance employee engagement. Society for Human Resource Management and Society for Industrial and Organizational Psychology.

García-Buades, E., Martínez-Tur, V., Ortiz-Bonnín, S., \& Peiró, J. M. (2016). Engaged teams deliver better service performance in innovation climates. European Journal of Work and Organizational Psychology, 25 (4), 597-612.

Gold, P. W. (2015). The organization of the stress system and its dysregulation in depressive illness. Molecular psychiatry, 20 (1), 32.

Gross, E. (2017). Work, organization, and stress. SocialStress. Chicago: Aldine. GrossWork, organization and stress Social Stress 1970, 54-110.

Huang, Y., Singh, P. V., \& Ghose, A. (2015). A structural model of employee behavioral dynamics in enterprise social media. Management Science, 61 (12), 2825-2844.

Huhtala, M., Tolvanen, A., Mauno, S., \& Feldt, T. (2015). The associations between ethical organizational culture, burnout, and engagement: A multilevel study. Journal of Business and Psychology, 30 (2), 399-414.

Izard, C. E. (2013). Human emotions. Springer Science \& Business Media. 
Jeve, Y. B., Oppenheimer, C., \& Konje, J. (2015). Employee engagement within the NHS: a cross-sectional study. International journal of health policy and management, 4 (2), 85.

Jiao, H., \& Zhao, G. (2014). When will employees embrace managers' technological innovations? The mediating effects of employees' perceptions of fairness on their willingness to accept change and its legitimacy. Journal of Product Innovation Management, 31 (4), 780-798.

Katzenbach, J. R., \& Smith, D. K. (2015). The wisdom of teams: Creating the highperformance organization. Harvard Business Review Press.

Kline, R. B. (2015). Principles and practice of structural equation modeling. Guilford publications.

Leiter, M. P., Day, A., \& Price, L. (2015). Attachment styles at work: Measurement, collegial relationships, and burnout. Burnout Research, 2 (1), 25-35.

Lu, C. Q., Wang, H. J., Lu, J. J., Du, D. Y., \& Bakker, A. B. (2014). Does work engagement increase person-job fit? The role of job crafting and job insecurity. Journal of Vocational Behavior, 84 (2), 142-152.

Luthans, F., Luthans, B. C., \& Luthans, K. W. (2015). Organizational behavior: An evidence-based approach. IAP.

Macey, W. H., Schneider, B., Barbera, K. M., \& Young, S. A. (2011). Employee engagement: Tools for analysis, practice, and competitive advantage (Vol. 31). John Wiley \& Sons.

Marshall, C., \& Rossman, G. B. (2014). Designing qualitative research. Sage publications.

Men, L. R., \& Tsai, W. H. S. (2015). Infusing social media with humanity: Corporate character, public engagement, and relational outcomes. Public Relations Review, 41 (3), 395-403.

Mergel, I. (2016). Social media institutionalization in the US federal government. Government Information Quarterly, 33 (1), 142-148.

Mone, E. M., \& London, M. (2014). Employee engagement through effective performance management: A practical guide for managers. Routledge.

Olla, W. W. (2013). The effect of organizational learning patterns on leading strategic change among higher education institutions of Ethiopia. Biola University.

Palinkas, L. A., Horwitz, S. M., Green, C. A., Wisdom, J. P., Duan, N., \& Hoagwood, K. (2015). Purposeful sampling for qualitative data collection and analysis in mixed method implementation research. Administration and Policy in Mental Health and Mental Health Services Research, 42 (5), 533544.

Pinder, C. C. (2014). Work motivation in organizational behavior. Psychology Press.

Pluut, H., Flestea, A. M., \& Curşeu, P. L. (2014). Multiple team membership: A demand or resource for employees?. Group Dynamics: Theory, Research, and Practice, 18 (4), 333.

Schabram, K., \& Maitlis, S. (2017). Negotiating the challenges of a calling: Emotion and enacted sensemaking in animal shelter work. Academy of Management Journal, 60 (2), 584-609. 
Short, K. (2016). Understanding the Impact of Recognition on Employees, Their Work, and Feelings Toward Managers. Benedictine University.

Slack, R. E., Corlett, S., \& Morris, R. (2015). Exploring employee engagement with (corporate) social responsibility: A social exchange perspective on organisational participation. Journal of Business Ethics, 127 (3), 537-548.

Snyder, T., \& Honig, D. (2016). Unleashing your silent majority: How employee advocacy and engagement build your brand and trust via digital strategies. Journal of Digital \& Social Media Marketing, 4 (3), 217-231.

Sonnentag, S., \& Fritz, C. (2015). Recovery from job stress: The stressordetachment model as an integrative framework. Journal of Organizational Behavior, 36 (S1).

Tims, M., Bakker, A. B., \& Derks, D. (2015). Examining Job Crafting from an Interpersonal Perspective: Is Employee Job Crafting Related to the WellBeing of Colleagues?. Applied Psychology, 64 (4), 727-753.

Valenzuela, S., Park, N., \& Kee, K. F. (2009). Is there social capital in a social network site?: Facebook use and college students' life satisfaction, trust, and participation. Journal of computer-mediated communication, 14 (4), 875901.

Vanclay, F., Esteves, A. M., Aucamp, I., \& Franks, D. M. (2015). Social Impact Assessment: Guidance for assessing and managing the social impacts of projects.

Wang, H. J., Lu, C. Q., \& Siu, O. L. (2015). Job insecurity and job performance: The moderating role of organizational justice and the mediating role of work engagement. Journal of Applied Psychology, 100 (4), 1249.

Whiting, S. W., \& Maynes, T. D. (2016). Selecting team players: Considering the impact of contextual performance and workplace deviance on selection decisions in the National Football League. Journal of Applied Psychology, 101 (4), 484. 
ISSN : 2337-3067

E-Jurnal Ekonomi dan Bisnis Universitas Udayana 9.2 (2020):181-198 